\title{
शोधसार लेखनको सैद्धान्तिक अवधारणा ₹ प्रयोग
}

\author{
केशव भुसाल \\ keshabbhusal.tu@gmail.com \\ उपप्राध्यापक \\ शिक्षाशास्त्र केन्द्रीय विभाग, त्रि.वि., कीर्तिपुर
}

\begin{abstract}
लेखसार
प्रस्तुत लेख अनुसन्धान तथा भाषिक अनुसन्धानको एक महत्त्वपूर्ण पक्ष शोधसार लेखनमा आधारित रहेको छ। यसअन्तर्गत शोधसार लेखनको सैद्धान्तिक परिचय र त्यसको प्रयोगबारे चर्चा गरिएको छ। शोधसार लेखनको परिचय दिनु, शोधसारका प्रकारहरू प्रस्तुत गर्नु, शोधसार लेखनमा ध्यान दिनुपर्ने कुराहरू उल्लेख गर्नु, शोधसारका अड्गहरूको व्यख्या गर्नु र शोधसारको नमुना प्रस्तुत गर्नु यस लेखका मुख्य उद्छेश्य रहेका छन्। प्रस्तुत लेखमा शोधसारबारे चर्चा गरिएका अङ्ग्रेजी सैद्धान्तिक सामग्रीहरूको सूक्ष्म अध्ययन गरिएको छ। जसका आधारमा शोधसार लेखन निश्चित विधि र प्रक्रियामा आधारित हुने, शोधसार लेखनमा यसका सैद्धान्तिक पक्षमा विशेष ध्यान दिनुपर्ने, व्याख्यात्मक, सूचनामूलक, समालोचनात्मक, चित्रात्मक आदि यसका मुख्य प्रकार हुने, परिचय, अध्ययन विधि वा प्रक्रिया, प्राप्ति र निष्कर्ष यसका मुख्य अड्गका रूपमा रहने लगायतका निष्कर्ष निकालिएको छ। प्रस्तुत अध्ययनमा गुणात्मक अनुसन्धान विधिको अवलम्बन गरिएको छ। यस अध्ययनबाट अनुसन्धान तथा भाषिक अनुसन्धान विषय शिक्षण गर्ने शिक्षक, अनुसन्धानरत विद्यार्थी एवम् अनुसन्धानका क्षेत्रमा क्रियाशील जोकोहीलाई पनि शोधसारको प्रकृति, यसको लेखन तथा प्रयोग-व्यवहारबारे जानकारी प्राप्त गर्न मद्दत पुग्ने अपेक्षा गरिएको छ।
\end{abstract}

प्रमुख शब्दावली : शोधसार, शोधसार लेखन, शोधसार प्ररूप, शोधसारगत पक्ष, शोधसारका अवयव ।

\section{अध्ययनको पृष्ठभूमि}

अनुसन्धानका क्षेत्रमा अनुसन्धान कार्य सम्पन्न गरिसकेपछि, शोधसार लेखिन्छ। कट्ट हेर्दा सामान्यजस्तो लागे पनि यसबारे सूक्ष्म अध्ययन-विश्लेषण गर्दा यो एउटा अलगै क्षेत्रका रूपमा देखा पई। अनुसन्धानका प्रारम्भिक कालखण्डमा यसबारे उल्लेख गरिएको नपाइए पनि समकालीन सन्दर्भमा यसलाई महत्तम पक्षका रूपमा लिने गरिएको छ। अर्थात् यसलाई अनुसन्धानात्मक शोधका लागि अपरिहार्य अड्ग्गका रूपमा स्वीकार गरिएको छ। शोधसारको लेखन स्वरूप, लेखनमा ध्यान दिनुपर्ने कुराहरू, यसको पूर्णताका लागि समेटिनुपर्ने विविध पक्षहरू लगायतमा वैविध्य देखा पई। नेपालका सन्दर्भमा पनि अन्तर्राष्ट्रिय जगत्मा जस्तै स्नातकोत्तर, एम. फिल. र विद्यावारिधि तहका शोधमा यसको प्रयोग व्यवहार अपेक्षाकृत रूपमा बढ़दै गइरहेको पाइन्छ। प्रस्तुत लेखमा अनुसन्धान तथा भाषिक अनुसन्धानका क्षेत्रमा आवश्यक पर्ने शोधसार लेखन र यसका विविध पक्षहरूका बारेमा सूक्ष्म अध्ययन-विश्लेषण गरिएको छ। 


\section{अध्ययनको उद्देश्य}

प्रस्तुत अध्ययनका उद्देश्यहरू निम्नानुसार रहेका छन् :

(क) शोधसार लेखनको सैद्धान्तिक परिचय दिनु

(ख) शोधसार लेखनका प्ररूपहरूको चर्चा गर्नु

(ग) शोधसार लेखनमा ध्यान दिनुपर्ने कुराहरू उल्लेख गर्नु

(घ) शोधसारका अवयवहरूको चर्चा गर्नु

(ङ) शोधसार लेखनको नमुना प्रस्तुत गर्नु ।

\section{अध्ययन विधि}

प्रस्तुत अध्ययन गुणात्मक अनुसन्धान विधिमा आधारित रहेको छ। यस अध्ययनमा पुस्तकालयीय अध्ययन विधिका माध्यमबाट आवश्यक सामग्रीहरूको सड्कलन गरिएको छ। यस अध्ययनमा विशेषतः अड्ग्रेजी सैद्धान्तिक सामग्रीहरूको अनुप्रयोग गरिएको छ। यस ऋममा शोधसार र यसका विविध पक्षबारे चर्चा गरिएका अड्ग्रेजी सैद्धान्तिक सामग्रीहरूबाट आवश्यक कुराहरू अध्याहार गरिएको छ। जसको व्याख्याविश्लेषणका लागि व्याख्यात्मक तथा विश्लेषणात्मक विधिको अवलम्बन गरिएको छ। यस अध्ययनमा अड्ग्र्रेजी सैद्धान्तिक सामग्रीहरूलाई प्राथमिक स्रोतका रूपमा उपयोग गरिएको छ भने शोधसार सम्बन्धमा चर्चा गरिएका लेखहरू र इन्टरनेटबाट प्राप्त सामग्रीहरूलाई द्वितीयक स्रोतका रूपमा उपयोग गरिएको छ। यस लेखमा सङ्कलित सामग्रीहरूको अध्ययनबाट प्राप्त तथ्यहरूलाई सूक्ष्म रूपमा विश्लेषण गरी प्रस्तुत गरिएको छ।

\section{शोधसारको परिचय}

शोधसार कुनै पनि अनुसन्धानको मुख्यसार हो । लाङ्कास्टर (१९९१) का अनुसार यो अनुसन्धानको सङ्क्षिप्त सारका रूपमा मात्र नरहेर सम्बन्धित शोधकार्यको वास्तविक प्रस्तुतिका रूपमा रहनु पर्दछ। यसलाई अनुसन्धानको एउटा महत्त्वपूर्ण अवयव मानिन्छ। शोधसार शोधकार्यको पहिलो मौलिक व्याख्या हो। शोधसारलाई विस्तृत रूपमा प्रस्तुत शोधकार्यका मुख्य-मुख्य कुराहरूको कमिक प्रस्तुतिका रूपमा लिइन्छ। यसमा अध्ययनबाट प्राप्त मुख्य निचोड वा नतिजालाई सड्क्षिप्त रूपमा प्रस्तुत गरिएको हुन्छ। यसबाट अनुसन्धाताको अनुसन्धानगत सक्षमता एवम् आत्मबलबारे जानकारी प्राप्त गर्न सकिन्छ । शोधसारलाई स्नातकोत्तर वा विद्यावारिधि तहको अनुसन्धानमा आधिकारिक भनाइ र व्याख्यासहित प्रस्तुत गरिने शोधसड्क्षेपणका रूपमा पनि व्याख्या गरिएको पाइन्छ। शोधसारलाई एउटा सानो शोध वा मिनी थेसिसका रूपमा पनि उल्लेख गरिएको पाइन्छ। शोधसार त्यस्तो सार हो जसले पाठकलाई पूर्ण रूपमा शोधपत्र अध्ययन नगर्दा पनि शोधपत्रमा निहित मुख्यमुख्य सबै कुराहरू ग्रहण गर्न सहयोग पुचाउँदछ। यसबाट पाठकहरूले शोधपत्रको कुन कुरा पढ़ने र कुन कुरा नपढ़ने भन्ने बारेमा निर्णय लिन सक्छन् । कुनै पनि लेख वा शोधकार्यको छिटो मूल्याङ्कनका लागि मूल्याङ्कनकर्ताहरूले त्यसको सारलाई आधार बनाउने गई्छ् । समग्र शोध पठनका निमित्त वा रखाइका निमित्त समय र स्थानको अभावका सन्दर्भमा शोधसार सिड्गो शोधपत्रलाई प्रतिस्थापन गर्न सक्ने प्रकृतिको हुनुपर्ने मानिन्छ। यसलाई सही र व्यवस्थित रूपमा उल्लेख गर्न सकेमा यसले पाठकलाई शोधबारे आवश्यक एवम् महत्त्वपूर्ण कुराहरूको जानकारी प्रदान गर्न मद्दत पुय्याउँदछ। कुनै पनि शोधको समग्र ज्ञान वा जानकारीका लागि भने सम्बन्धित शोधकार्य नै अध्ययन गर्नुपर्ने हुन्छ। 
शोधसार लेखनको सैद्धान्तिक अवधारणा $₹$ प्रयोग / 155

\section{शोधसारका प्रकार}

शोधसारलाई विभिन्न प्रकारमा वर्गीकरण गरिएको पाइन्छ। यसका प्रमुख प्रकारहरू निम्नानुसार रहेका छन् :

(क) व्याख्यात्मक शोधसार (डिस्क्रिप्टिभ अर इन्डिकेटिभ एब्ट्ट्याक्ट)

व्याख्यात्मक शोधसारलाई सीमित सार वा सूचकात्मक सार पनि भनिन्छ। यसमा शोधकार्यका सूचनाहरू अत्यन्त स्थूल रूपमा वा सङ्क्षिप्त रूपमा आएका हुन्छन्। यसलाई शोधकार्यको विषय सचीलाई अनुच्छेदमा प्रस्तुत गरिएको स्वरूपका रूपमा समेत व्याख्या गरिएको पाइन्छ। यसमा शोधकार्य केमा गरिएको हो भन्नेबारे सूचना दिने काम हुन्छ। यो प्रायः १०० शब्दको हुने मानिन्छ। यसमा शोधको उद्देश्य, क्षेत्र र विधिबारे उल्लेख गरिएको हुन्छ। तर शोधको परिणाम, निष्कर्ष, सुकाव र उपादेयताबारे भने उल्लेख गरिएको हुँदैन ।

(ख) सूचनामूलक शोधसार (इन्फर्मेटिभ एब्ट्य्याक्ट)

सूचनामूलक शोधसारलाई पूर्ण शोधसार पनि भनिन्छ। यसमा शोधकार्यका समग्र कुराहरूलाई सूक्ष्म वा विस्तृत रूपमा प्रस्तुत गरिएको हुन्छ। यसमा अध्ययनको परिचय वा पृष्ठभूमि, अध्ययनको उद्देश्य, अध्ययन विधि, अध्ययनको परिणाम, निष्कर्ष, सुकाव र उपादेयतालगायतका कुराहरू समेटिएका हुन्छन् । यसको आकार सड़क्षिप्त भए पनि एक-दुई पृष्ठको हुन्छ। यसको लमाइ १००-२०० शब्दसम्मको हुने मानिन्छ। यसमा शोधकार्यको पूर्ण सार खिचिएको हुन्छ। सम्प्रति यस प्रकृतिको शोधसार लेख्ने प्रचलन रहेको छ।

\section{(ग) समालोचनात्मक शोधसार (क्रिटिकल एब्स्ट्याक्ट)}

समालोचनात्मक शोधसार सघन समालोचनात्मक दृष्टिकोणमा आधारित शोधसार हो। यसलाई शोधकार्यको मूल्याङ्कनात्मक सारका रूपमा लिने गरिन्छ। यसमा शोधार्थीद्वारा सम्बन्धित क्षेत्रमा गरिएका अन्य शोधकार्यसँग तुलना गरेर आफ्नो शोधकार्यका सबल र दुर्बल पक्ष उल्लेख गरिएको हुन्छ।

\section{(ग) चित्रात्मक शोधसार (ग्राफिकल एब्ट्य्याक्ट)}

सन् २००० को दशकपछि कम्प्युटरको प्रभावस्वरूप चित्रात्मक शोधसारको प्रचलनसमेत हुन थालेको पाइन्छ। यसलाई एकै दृष्टिमा लेख वा शोधको प्रकृति, क्षेत्र, उद्देश्य, विधि, निष्कर्ष, उपादेयता आदि ग्रहण गर्न सकिने प्रकृतिको चित्रात्मक प्रस्तुतिका रूपमा लिइन्छ। कतिपय सन्दर्भमा यसको प्रस्तुति श्रव्यदृश्यात्मक समेत हुने मानिन्छ । खासगरी वैज्ञानिक प्रकाशनहरूमा यसको प्रयोगव्यवहार बढ़दै गइरहेको पाइन्छ।

\section{शोधसार लेखनमा ध्यान दिनुपर्ने कुराहरू}

शोधसारलाई शोधकार्यको मुख्य भागका रूपमा समेत लिइन्छ। तसर्थ यसको लेखनमा लापरबाही नगरी सावधानी अपनाउनु अपरिहार्य हुन्छ। उपयुक्त एवम् उत्तम शोधसार लेखनमा निश्चित आधार वा तौरतरिकाको अवलम्बन गर्नुपर्ने हन्छ। शोधसार लेखनमा निम्नानुसारका तौरतरिकाको अवलम्बन गर्नु वान्छनीय मानिन्छ : 
- सर्वप्रथम आप्नो शोधअन्तर्गत गई उद्देश्य, क्षेत्र, विधि, निष्कर्ष र अन्य महत्त्वपूर्ण सूचनाको निश्चयन गर्नुपछ।

- त्यसपछि शोधकार्यमा उल्लेख गरिएका उद्देश्य, विधि, निष्कर्ष लेखनुपई ।

- यस कार्यपश्चात् आफ्नो शोधकार्यको उपलब्धिलाई निश्चित गर्नुपई ।

- निश्चित गरिएका समग्र कुराहरूलाई जम्मा गरी एक अनुच्छेदमा लेख्तुपई।

- शोधसारको स्वरूप राम्रो बनाउनका लागि सड्कलित सबै सूचनाहरूलाई पुनर्लेखन गर्नुपई।

- पहिलो वाक्य शोधकार्य के विषयमा आधारित छ वा केसँग सम्बन्धित छ भन्ने कुराबाट प्रारम्भ गर्नुपई। अर्थात् शोधसार लेखनको आरम्भ 'यो शोध' नामक पदावलीबाट गर्नुपछ।

- लिखित शोधसारमा आवश्यक कुरा छुटेनछुटेको, वर्णविन्यासगत त्रुटि भएनभएको वा अनावश्यक कुराहरू आएनआएको कुरा ख्याल गरी शोधसारलाई परिमार्जन गर्नुपईछ।

- शोधसारमा सामान्यतः सन्दर्भ स्रोत वा उद्धरण उल्लेख गरिदैन । यद्यपि शोधको परिणाम प्रस्तुतिका कममा स्रोत उद्घृत गरेको पनि पाइन्छ।

- शोधपत्रमा शोधसारलाई अलगैै नयाँ पृष्ठमा प्रस्तुत गर्नुपई ।

- शोधसारको शीर्षक पृष्ठको माथि बीच भागमा शोधसार भनी उल्लेख गर्नुपई।

- शोधसार शीर्षकलाई बोल्ड (गाढा), इटालिक (छड्केलेखन) वा अन्डरलाइन (रेखाङ्कन) गर्नु हुँदैन ।

- शोधसार लेखनमा सम्प्रति मुख्य शब्दावली पनि राख्ने गरिएको पाइन्छ।

- शोधपत्रमा यसलाई आवरण पृष्ठपछि राख्ने प्रचलन रहेको छ। (कसैकसैले शोधसारलाई शोधान्तमा राखेको दृष्टान्त पनि पाइन्छ। यद्यपि आवरण पृष्ठपछि नै राख्नु उपयुक्त हुन्छ।

\section{शोधसार लेखनमा अपनाउनुपर्ने सावधानी}

- शोधसार शोध सम्पन्न भएपछि मात्र लेख्नुपर्दछ।

- शोधसारमा सबै महत्त्वपूर्ण सूचनाहरू सड़क्षिप्त रूपमा आएको हुनुपर्दछ।

- पाठकले शोधबारे प्रस्ट जानकारी पाउने गरी शोधसार लेख्नुपर्दछ।

- शोधसारमा अनावश्यक र अतिरिक्त सूचना राखिनु हुँदैन ।

- सड्क्षिप्त शब्दको प्रयोग गर्ने भए पहिले पूरा रूप लेखी कोष्ठकमा सड्क्षिप्त शब्द लेख्नु पर्दछ, अनि मात्र सड्क्षिप्त शब्दको प्रयोग गर्नुपर्दछ।

- शोधसारमा छिटो र स्पष्टसंग सूचना ग्रहण गर्नमा सहयोग पुग्ने गरी सरल भाषाको प्रयोग गर्नुपर्दछ।

- शोधसारमा अनुसन्धान प्रश्नको उत्तर आएको हुनुपर्दछ।

- शोधसारमा परिणाम प्रस्तुत नगर्नुलाई साका समस्याका रूपमा लिइन्छ।

- शोधसारमा आफूले के गरियो भन्ने कुरा उल्लेख नगरी के पत्ता लगाइयो भन्ने कुरा उल्लेख गर्नुपर्दछ।

- शोधसार लेखनमा प्राय:भूतकालको प्रयोग अपेक्षा गरिन्छ तथथापि यसमा सन्दर्भअनुसार वर्तमान, भूत र भविष्यत् कालको प्रयोग गर्न सकिन्छ।

उल्लिखित चर्चाबाट के अवधेय हुन्छ भने शोधसार लेखनका क्रममा शोधको क्षेत्र, अध्ययन प्रक्रिया, अध्ययनीय निष्कर्ष र उपादेयतालाई मूलभूत रूपमा उल्लेख गर्नुपर्ने हुन्छ। 


\section{शोधसारका अवयव वा तत्त्वहरू}

कुनै पनि विधागत अनुसन्धानको शोधसारका लागि निम्नानुसारका अवयवहरू आधारभूत अवयव वा तत्त्व बन्छन् । अर्थात् यसको संरचनामा निम्न पक्षहरू रहन्छन् :

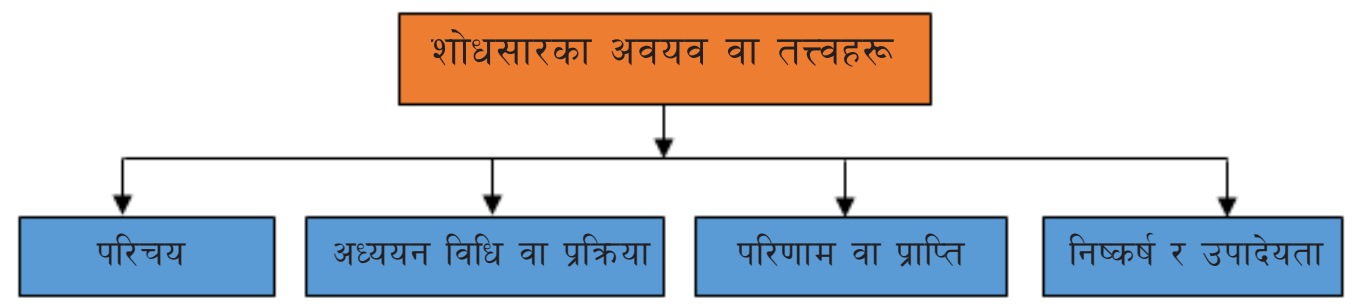

\section{परिचय}

शोधसारको पहिलो अवयव परिचय हो। यसमा शोधकार्य केमा गरिएको हो ? वा शोधकार्य केमा आधारित छ ? वा शोधले केमा जोड दिएको छ ? शोधकार्य वा अनुसन्धान सैद्धान्तिक, प्रयोगात्मक, कलात्मक वा वैज्ञानिक कुन क्षेत्रमा रिक्तता देखिएर गरिएको हो ? केकस्ता उद्देश्य राखेर गरिएको हो ? लगायतका कुराहरू समेटिएको हुनुपर्दछ। मात्रात्मक दृष्टिले परिचयलाई एक अनुच्छेदमा उल्लेख गर्नु उपयुक्त हुन्छ।

\section{अध्ययन विधि र प्रक्रिया}

यो शोधसारको दोस्रो अवयव हो। यसमा शोधकार्यको परिणामसम्म पुगदा गरिएका समग्र कार्यहरू उल्लेख गर्नुपर्दछ। -उदाहरणका लागि आफूले गरेको अनुसन्धानको प्रकृति गुणात्मक, परिमाणात्मक वा मिश्रित कुन हो ? कति वटा उपन्यास, कथा वा विधाको अध्ययन गरिएको हो ? नमुना लिइएको भए लिइएका नमुनाको सड्ख्या कति हो ? अन्तर्वार्ता लिइएको भए कति जनाको अन्तर्वार्ता लिइएको हो ? आदि कुराहरू उल्लेख गर्नुपर्दछ।

\section{परिणाम वा प्राप्ति}

यो शोधसारको तेस्रो अवयव हो । यसमा शोध प्रक्रियाबाट सम्पन्न गरिएको शोधकार्यबाट के सिकियो ? के आविष्कार गरियो ? के सृजना गरियो ? लगायतका कुराहरू उल्लेख गर्नुपर्दछ। यसलाई शोधकार्य वा अनुसन्धानबाट निस्पादित मुख्य परिणामहरू उल्लेख गर्ने क्षेत्रका रूपमा लिन सकिन्छ।

\section{निष्कर्ष र उपादेयता}

यो शोधसारको अन्तिम अवयव, तत्त्व वा चरण हो। यसमा शोधकार्यको मुख्य निष्कर्ष प्रस्तुत गरिएको हुन्छ। यसअन्तर्गत पहिलो चरणमै उल्लेख गरिएको अनुसन्धानको रिक्तता पूरा गर्नका लागि आफूले निकालेको निष्कर्षको दीर्घकालीन उपादेयता के हो ? अनुसन्धान कसका लागि उपयोगी बन्न सक्छ ? लगायतका कुराहरू उल्लेख गर्नुपर्दछ। यससंगै शोधसार लेखनको कार्य समापन हुन्छ।

\section{शोधसारको आकार र स्वरूप}

लड्कास्टर (सन् १९९१) का अनुसार शोधसारको लम्बाइमा निम्न सात तत्त्वहरूले प्रभाव पार्दछन् : 
- शोधको लम्बाइ

- विषयवस्तुको जटिलता

- विषयवस्तुगत विविधता

- शोधसार सड्गठन गर्दा आवश्यक तत्त्व वा एकाइको महत्त्व

- विषयवस्तुको उपलब्धता

- शोधसारको मूल्य

- शोधको उद्देश्य ।

एपिए (अमेरिकन साइकोलजिकल एसोसिएसन) का अनुसार लेखसार लेखनमा निम्नलिखित कुरामा ध्यान दिनुपर्दघः :

- लेखसार १४० देखि २०० शब्दसम्मको हुनुपर्दछ।

- लेखसार एक अनुच्छेदमा लेख्तुपर्दछ।

- लेखसार परिचयको सारबाट लेख्न सुरु गर्नुपर्दछ।

- त्यसपछि विधिको सार लेख्नुपर्दछ अनि परिणाम र व्याख्याको सार लेख्नुपर्दछ।

शोधसारको आकार र स्वरूप सम्बन्धमा निम्नानुसारको धारणा समेत पाउन सकिन्छ :

- शोधसारमा शब्द सीमितता १००-५०० शब्दसम्म हुन सक्छ।

- क्यानडाको नेसनल आर्चिभले स्नातकका लागि १५० र पीएचडी का लागि ३५० शब्दको शोधसार हुनुपर्ने कुरा उल्लेख गरेको पाइन्छ।

- शोधसार १७४ देखि ३०० शब्द लामो हुनुपर्ने मान्यता पनि रहेको पाइन्छ।

- पूर्वकार्य पुनरावलोकनमा पू० शब्द, विधिको प्रस्तुतिमा १२० शब्द र बाँकी शब्दमा प्राप्ति उल्लेख गर्नुपर्ने धारणा समेत रहेको देखिन्छ।

- आनुच्छेदिक दृष्टिले हेर्दा कुनै पनि लेखमा शोधसारलाई एउटा अनुच्छेदमा राख्ने प्रचलन रहेको छ भने शोधपत्रका सन्दर्भमा विविधता देखा पर्दछ।

शोधसारका सन्दर्भमा उल्लिखित विविध धारणा रहेका भए पनि शोधसार कति शब्द र अनुच्छेदमा लेख्ने भन्ने कुरा शोधको विधागत क्षेत्र वा संस्थाको नियममा भर पर्ने हुन्छ।

यद्यपि शोधसारमा निम्न कुराहरूको अवलम्बन अपेक्षित हुन्छ :

- स्नातकोत्तर तहको शोधकार्यमा ३०० शब्दसम्मको शोधसार लेख्नु उपयुक्त हुन्छ।

- शोधसारलाई एकाधिक अनुच्छेदमा प्रस्तुत गर्नु उपयुक्त हुन्छ।

- यस क्रममा पहिलो अनुच्छेदमा परिचय र उद्देश्य, दोस्रो अनुच्छेदमा अध्ययन विधि र प्रक्रिया, तेस्रो अनुच्छेदमा निष्कर्ष वा प्राप्ति र चौथो अनुच्छेदमा उपादेयता राख्तु उचित हुन्छ।

- विद्यावारिधि तहका शोधका सन्दर्भमा १००० शब्दसम्मको शोधसार हुनु उपयुक्त हुन्छ। यस तहको शोधसारमा तेस्रो अनुच्छेदलाई निष्कर्ष वा प्राप्तिको मात्राअनुसार एकाधिक अनुच्छेदको बनाउनु सान्दर्भिक हुन्छ। 
शोधसार लेखनको सैद्धान्तिक अवधारणा ₹ प्रयोग/ 159

शोधसारमा कालको प्रयोग

शोधसार लेखनमा सूचनाको प्रकृतिअनुसार कालिक क्रियाको प्रयोग हुने गई। जसलाई निम्नानुसार प्रस्तुत गर्न सकिन्छ :

\begin{tabular}{|c|c|c|}
\hline सूचनाका प्रकार & क्रियाको प्रयोग & उदाहरणहरू \\
\hline $\begin{array}{l}\text { अध्ययनीय पृष्ठभूमिको } \\
\text { विस्तृति }\end{array}$ & वर्तमान काल & - सड्कथनलाई भाषाको सग्लो एकाइका रूपमा लिइन्छ। \\
\hline अनुसन्धानात्मक & सामान्य भूतकाल & - यो अध्ययन दुई मुख्य क्षेत्रमा केन्द्रित रहेको छ। \\
\hline क्रियाकलापको व्याख्या & $\begin{array}{l}\text { र पूर्ण वर्तमान } \\
\text { काल }\end{array}$ & $\begin{array}{l}\text { - यस अध्ययनमा निर्दिष्ट विधाको सड्कथन } \\
\text { विश्लेषणका लागि आवश्यक रूपरेखाको विकास } \\
\text { गरिएको छ। }\end{array}$ \\
\hline \multirow[t]{3}{*}{$\begin{array}{l}\text { अनुसन्धान विधिको } \\
\text { व्याख्या }\end{array}$} & $\begin{array}{l}\text { सामान्य भूतकाल } \\
\text { (कर्तृवाक्य र }\end{array}$ & $\begin{array}{l}\text { - यस अध्ययनमा क्षेत्रीय अध्ययन विधिको प्रयोग } \\
\text { गरियो। }\end{array}$ \\
\hline & अकतृ & $\begin{array}{l}\text { - यस अनुसन्धानमा जातिभाषिक अध्ययन विधिको } \\
\text { प्रयोग गरें। }\end{array}$ \\
\hline & & $\begin{array}{l}\text { - यस अध्ययनमा लिइएका नमुनाहरूको परीक्षण } \\
\text { गरियो/गरें। }\end{array}$ \\
\hline परिणामको प्रस्तुति & सामान्य भूतकाल & $\begin{array}{l}\text { - यस अध्ययनको परिणामले के देखायो भने अध्ययन } \\
\text { गरिएको समस्या पूर्वानुमान गरिएको भन्दा थप } \\
\text { गम्भीर रहेको छ। }\end{array}$ \\
\hline निष्कर्षण & वर्तमान काल & $\begin{array}{l}\text { - यसले के सङ्केत गई भने यस्तो स्थिति देखिनुमा } \\
\text { विभिन्न तत्त्वको भूमिका रहेको छ। }\end{array}$ \\
\hline
\end{tabular}

समग्रतः शोधसार लेखनमा निम्नानुसारका पक्षमा ध्यान दिनुपर्दछ :

सुरुवात शोधसार लेखन नयाँ पृष्ठबाट सुरु गर्नु पर्दछ।

शीर्षक शोधसार शीर्षकलाई पृष्ठको बीचमा राख्नुपर्दछ। (शीर्षकलाई बोल्ड वा गाढालेखन, इटालिक वा छड्केलेखन, अन्डरलाइन वा रेखाङ्कन नगरी सामान्य रूपमा प्रस्तुत गर्नु पर्दछ, ।)

शब्दसड्ख्या शोधसार १४०-१००० शब्दसम्मको हुन सक्छ। यसको निर्धारण तह र संस्थामा निर्भर हुन्छ।

फन्ट शोधसार लेखनमा अड्ग्रेजीमा टाइम्स न्यू रोमन प्रयोग गरिने भए पनि नेपालीमा प्रिति फन्ट प्रयोग गर्नु उपयुक्त हुन्छ।

आउनुपर्ने कुरा, शोधसारमा शोधको परिचय, शोधको उद्देश्य, अध्ययन विधि, प्राप्ति, निष्कर्ष र उपादेयता तत्त्व वा अवयव उल्लेख गर्नुपर्दछ।

भाषा शोधसारमा प्रायः कर्मवाच्यको प्रयोग गर्नुपर्दछ। यसमा सन्दर्भअनुसार वर्तमान, भूत र भविष्यतकालीन क्रियाको प्रयोग गर्न सकिन्छ। 
सङ्क्षिप्त शब्द शोधसारमा सङ्क्षिप्त शब्दको प्रयोग गर्नुपर्ने छ भने सर्वप्रथम सङ्क्षिप्त शब्दको पूरा प्रयोग रूप लेखी कोष्ठकमा सङक्षिप्त रूप उल्लेख गरेपहि मात्र सङक्षिप्त रूपको प्रयोग गर्नुपर्दछ।

मुख्य सम्प्रति शोधसारमा समेत मुख्य शब्दावली राख्न सकिने धारणा विकास भएको छ। यस शब्दावली ऋममा माथिल्लो लहर (लाइन) को बाँया भागबाट पाँच स्पेस दिएर मुख्य शब्दावली राख्नुपर्ने हुन्छ। मख्य शब्दावलीलाई इटालिक (छड्केलेखन) गर्नु पर्दछ।

\section{शोधसार लेखन}

शोधसार लेखन निम्नानुसारले गर्न सकिन्छ : :

\section{शोधसार}

(स्नातकोत्तर तहको शोधसार)

प्रस्तुत शोध भाषाशिक्षणमा प्रचलित पारिभाषिक शब्दावलीको अध्ययनमा आधारित परिचय रहेको छ। यस शोधमा नेपाली भाषाशिक्षणमा प्रयोग प्रचलनमा रहेका पारिभाषिक शब्दावलीहरूको अध्ययन विश्लेषण गरिएको छ। भाषाशिक्षणमा प्रचलित पारिभाषिक शब्दावलीहरूको सङ्कलन गर्नु; सङ्कलित शब्दावलीहरूलाई वर्णानुक्रममा प्रस्तुत गर्नु, पारिभाषिक शब्दावलीहरूको प्रकृति पत्ता लगाउनु र तिनको प्रयोगगत अवस्था अध्ययन गर्नु प्रस्तुत शोधका उद्देश्य रहेका छन् ।

प्रस्तुत अध्ययन गुणात्मक अनुसन्धानमा आधारित अनुसन्धान हो । यस अध्ययनमा पुस्तकालयीय कार्यका माध्यमबाट सोद्देश्यमूलक तरिकाले सामग्रीहरूको सड्कलन गरियो। यस अनुसन्धानमा भाषाशिक्षणसंग सम्बन्धित पाठ्यपुस्तकहरूलाई प्राथमिक सामग्रीको रूपमा लिई अध्ययन गरियो। यस ऋममा प्रवीणता प्रमाणपत्र तहदेखि स्नातकोत्तर तहसम्मका लागि लेखिएका भाषाशिक्षणका पाठ्यपुस्तकहरूलाई नै विशेष आधार बनाइयो। प्रस्तुत अध्ययनमा नेपाली, अंग्रेजी र हिन्दी सैद्धान्तिक सामग्रीहरूको अध्ययन गरी आवश्यक सैद्धान्तिक दृष्टिकोणको विकास गरी त्यसका आधारमा पारिभाषिक शब्दावलीको अध्ययन विश्लेषण गरियो।

निष्कर्ष प्रस्तुत अध्ययनबाट पारिभाषिक शब्दावली, तिनको प्रकृति, प्रयोग अवस्थाबारे विविध तथ्यहरू प्राप्त भएका छन्। यस अध्ययनका आधारमा भाषाशिक्षणमा व्याकरण, भाषाविज्ञान र साहित्यसँग सम्बन्धित विभिन्न पारिभाषिक शब्दावलीको प्रयोग व्यवहार हुने गरेको पाइयो। भाषाशिक्षणका क्षेत्रमाअनेकाक्षरी एवम् संज्ञामूलक शब्दहरूको अधिक प्रयोग हुने गरेको तथ्य प्राप्त भयो। साथै तत्सम र आगन्तुक पारिभाषिक शब्दहरूको प्रयोग ज्यादा हुने गरेको देखियो। 
शोधसार लेखनको सैद्धान्तिक अवधारणा $₹$ प्रयोग / 161

प्रस्तुत अध्ययनले भाषाशिक्षणको क्षेत्रमा कार्यरत वा कार्य गर्न चाहने शिक्षक, विद्यार्थी, शोधार्थी, लेखक तथा विषय विशेषजलाई यस क्षेत्रका पारिभाषिक शब्दावलीबारे आवश्यक कुराहरू अधिगत गर्न सघाउने अपेक्षा गरिएको छ। साथै भाषाशिक्षणका क्षेत्रमा अध्ययन गर्न चाहने शोधार्थीका लागि प्रस्तुत अध्ययन उपयोगी हुने आशा राखिएको छ।

(शब्द सड़्या : २३०)

\section{शोधसार}

(विद्यावारिधि तहको शोधसार)

प्रस्तुत अनुसन्धान आख्यानात्मक विधाको सङ्कथन अध्ययनमा आधारित अनुसन्धान हो । माध्यमिक तहका आख्यानात्मक विधाहरूको साङ्कथनिक अध्ययन गर्नु यस अनुसन्वानको मूलभूत उद्देश्य हो भने सङ्कथन विश्लेषणको सैद्धान्तिक प्रतिमान निर्माण गर्नु, माध्यमिक तहका नेपाली आख्यानात्मक विधाहरूको संसक्तिपरक अध्ययन गर्नु, उक्त तहका आख्यानात्मक विधाहरूको संयुक्तिपरक अध्ययन गर्नु र आख्यानात्मक विधाका पाठहरूको शैक्षणिकता विश्लेषण गर्नु यसका सहायक एवम् विशिष्ट उद्देश्यहरू हुन् ।

प्रस्तुत अनुसन्धान गुणात्मक अनुसन्धान विधिमा आधारित अनुसन्धान हो। यस अनुसन्धानमा पुस्तकालयीय कार्यका माध्यमबाट सोद्देश्यमूलक तरिकाले सामग्रीहरूको सङ्कलन गरियो। सामग्री सङ्कलनका ऋममा प्राथमिक र द्वितीयक स्रोतको उपयोग गरियो। यस क्रममा माध्यमिक तह (कक्षा ९ र १०) को नेपाली भाषापाठ्यपुस्तकमा समाविष्ट आख्यानात्मक विधाका पाठहरूमध्ये कथाहरूलाई प्राथमिक सामग्रीका रूपमा लिइयो भने द्वितीयक सामग्रीका रूपमा सङ्कथन र सड्कथन विश्लेषणसम्बद्ध आधिकारिक अड्ग्रेजी लेखकहरूका सैद्धान्तिक पुस्तकहरू, महत्त्वपूर्ण लेखरचनाहरु, सङ्कथनसम्बद्ध विभिन्न विदेशी स्वदेशी शोधपत्रहरू एवम् सन्दर्भ सामग्रीहरूलाई लिइयो। प्रस्तुत शोधमा सङ्कथन र सड्कथन विश्लेषणसम्बद्ध अड्ग्रेजी सैद्धान्तिक सामग्रीहरूको अध्ययन गरी आख्यानात्मक विधाको साङ्कथनिक अध्ययन-विश्लेषणार्थ आवश्यक प्रतिमान निर्माण गरियो। यस कममा विशेषतः भाषावैज्ञानिक हालिडे र हसनको कोहिजन इन इड्गलिस र ल्याङ्रिविज कन्टेक्स्ट एन्ड टेक्स्ट : आस्पेक्ट अफ ल्याङ्रिवज इन अ सोसिअल सेमिओटिक पर्सपेक्टिभ नामक पुस्तकको अनुप्रयोग गरियो। साथै साल्के, एलेन र कर्डर, विडोसन, क्यारेल, ह्यारिस, रेडेकर लगायतका भाषाशास्त्रीहरूका सामग्रीहरुको समेत उपयोग गरियो। जसका आधारमा माध्यमिक तहका आख्यानात्मक विधाहरूको सङ्कथन अध्ययन विश्लेषणार्थ संसक्ति-संयुक्ति युक्ति र यीअन्तर्गतका विभिन्न भेद उपभेदहरूको निर्धारण गरियो। यस ऋममा संसक्तिअन्तर्गत व्याकरणिक र कोशीय संसक्ति तय गरियो भने संयुक्तिअन्तर्गत अन्तर्वाक्यीय, अन्तर्अनुच्छेदीय र सन्दर्भपरक भेदहरूको निर्धारण गरियो।

आख्यानात्मक विधाको सङ्कथन विश्लेषणसम्बद्ध यस अनुसन्धानबाट विभिन्न नवीनतम् तथ्यहरु प्राप्त भएका छन् । जसलाई निम्नानुसार उल्लेख गरिएको छ:

माध्यमिक तहका आख्यानात्मक विधामा सङ्कथन संसक्तिका मुख्य प्रकार : व्याकरणिक र कोशीय संसक्तिको प्रयोग-व्यवहार गरिएको पाइयो। जसमध्ये व्याकरणिक संसक्तिअन्तर्गत सन्दर्भन, प्रतिस्थापन, 
विलोपन र संयोजन संसक्ति तथा कोशीय संसक्तिअन्तर्गत पुनरुक्ति र सन्निधान संसक्तिको प्रयोग गरिएको देखियो ।

सैद्धान्तिक दृष्टिकोणअनुसार सन्दर्भन संसक्तिका रूपमा प्रथम, द्वितीय र तृतीय पुरुष सर्वनामको प्रयोग हुने हालिडे र हसन (सन् १९७६) मान्यता रहेको भए पनि माध्यमिक तहका आख्यानात्मक विधामा पारस्परिक सर्वनाम (उदा. परस्पर, आपस आदि) र सम्बन्धवाचक विशेषण शब्दहरू (उदा. मेरो, उनको, हाम्रो, तिम्रो आदि) को समेत प्रयोग गरिएको पाइयो। जुन साल्के (सन् 9९९५) द्वारा प्रस्तुत दृष्टिकोणसँग सम्बद्ध देखापछ। साथै यसअन्तर्गत क्रियायोगी शब्दहरू (उदा. यसैगरी, यसरी आदि) ले समेत सन्दर्भनको कार्य सम्पादन गरेको पनि पाइयो। माध्यमिक तहका आख्यानात्मक विधामा हालिडे र हसन (सन् १९७६) तथा अन्यद्वारा प्रस्तुत दर्शकवाचक सन्दर्भकका अतिरिक्त तत्तात्पर्यमा कार्य सम्पादन गर्ने विभिन्न निर्धारकहरूको समेत प्रयोग (उदा. एक वडा प्रतापी राजा, दुबै पतिपत्नी, एउटा छोरो, सारा चाकरिया आदि) गरिएको पाइयो ।

सैद्धान्तिक दृष्टिकोणअनुसार सङ्कथनमा प्रतिस्थापन संसक्ति पूर्वप्रयुक्त भाषिक घटकलाई स्थानापन्न गर्ने रूपमा आउने मानिए पनि प्रस्तुत अध्ययनका आधारमा हेर्दा यो कतिपय सन्दर्भमा पश्चप्रस्तुत विषयलाई प्रतिस्थापन गर्न पहिले नै व्यवहृत हुने गरेको (उदा. न्यायको पक्ष कथाको सत्रों अनुच्छेदमा भाइहरूको प्रयोग पूर्ववर्ती रूपमा र अर्जुन, भिमसेनलगायतको चर्चा तत्पश्चात् भएको) देखियो । माध्यमिक नेपाली आख्यानात्मक विधामा अड्ग्रेजी भाषामा जस्तो साभा नामिक, क्रियात्मक र उपवाक्यात्मक प्रतिस्थापकहरूको प्रयोग भएको पाइएन। तदपि सन्दर्भअनुसार पूर्वप्रयुक्त नाम, क्रिया र उपवाक्यलाई स्थानापन्न गर्ने विभिन्न प्रतिस्थापन शब्दहरूको भने प्रायोग-व्यवहार गरिएको पाइयो।

वस्तुतः विलोपन संसक्तिको बोध पूर्वप्रस्तुत विषयको विलोपन भएको पश्चसन्दर्भका आधारमा हुने सैद्धान्तिक मान्यता रहेको भए पनि माध्यमिक तहको आख्यानात्मक विधाको अध्ययनबाट यसको बोध यसको ठीक विपरीत समेत हुने (उदा. अहिले (न्यायी) निर्धो देखियास् या बलियो, परिणाममा न्यायीको नै जित हुन्छ भन्ने मलाई दृढ निशचय छु : न्यायको पक्ष कथा) देखियो। सङ्कथन संसक्ति अध्ययनका ऋममा नामिक विलोपनअन्तर्गत सर्वनाम तथा सम्बन्धवाचक विशेषणलाई लिइने नलिइनेबारे स्पष्ट धारणा नपाइए पनि प्रस्तुत अध्ययनका आधारमा सर्वनाम तथा सम्बधवाचक विशेषण शब्दहरूको विलोपनलाई समेत नामिक विलोपनअन्तर्गत समेट्न सकिने दृष्टिकोणको विकास गरिएको छ। जसको स्थिति अत्यधिकसमेत देखा पय्यो ।

माध्यमिक तहका आख्यानात्मक विधामा कोशीय संसक्तिअन्तर्गत पुनरावृत्तिको अत्यधिक प्रयोग गरिएको पाइयो। यस ऋममा पुनरावृत्ति शब्दलाई पूर्ण रूपमा मात्र नभई अपूर्ण (छोटकरी) रूपमा समेत प्रयोग गरिएको (उदा. सन्तान=सन्ता, बुबा=बा आदि) देखियो । सिद्धान्ततः कोशीय संसक्तिअन्तर्गतको सन्निधान संसक्तिले निकटता वा वाक्यान्तरिक घटकका बीचको सान्निध्य जनाउने मानिए पनि माध्यमिक नेपाली आख्यानात्मक विधामा यसले अन्तर्वाक्यीय रूपमा समेत कार्य सम्पादन गरेको (उदा. कर्तव्य कथाको अनुच्छेद दसमा प्रयुक्त वकपत्र-साक्षी, छब्बीसमा प्रयुक्त घर-आँगन, अट्ठाइसमा प्रयुक्त वरियात-वरणी आदि) देखियो । 
शोधसार लेखनको सैद्धान्तिक अवधारणा $₹$ प्रयोग/ 163

माध्यमिक नेपाली आख्यानको संयुक्तिपरक अध्ययन-विश्लेषणका क्रममा कुल ३३ वटा अन्तर्वाक्यीय संयुक्ति सम्बन्धहरूको प्रयोग-व्यवहार भएको पाइयो। जसमध्ये सबैभन्दा बढी शिशिर र वसन्तको कथामा यसको प्रयोग पाइयो। वस्तुतः माध्यमिक तहका सबै कथामा एकै किसिमका अन्तर्वाक्यीय संयुक्ति सम्बन्वहरूको प्रयोग नपाइए पनि कुल ११ वटा सम्बन्वहरू (कार्य-कारण, कारण-कार्य, कारण-परिमाण, आर्थी विपर्याय, व्याख्यात्मक, अप्रत्यक्ष, अनुमानित, आनुक्रमिक, समुच्चयात्मक, विध्यर्थक र प्रश्नार्थक) सबै कथामा व्यवहृत भएको देखियो। समाविष्ट छ कथाहरूमध्ये भविष्य निर्माण कथामा व्यवहृत संयुक्ति विन्यासमा केही कमीकमजोरी (उदा. सड्गतिमा त्रुटिः तुङसुङ बस्तीतिर जाने मानिस त्यस घरतर्फ आकर्षित हुन्छ, सन्दर्भान्तरः नरेशले दुष्ट को हुन् आमा ? भनी राखेको जिज्ञासामा दुष्ट जर्मन हुनुपर्नेमा 'दुष्ट' शब्दको परिचयात्मक व्याख्या प्रस्तुत गरिएको आदि) रहेको पाइयो । जसका कारण कथात्मक विषय बोधमा सामान्य समस्या सृजना भएको देखियो ।

अनुच्छेद विन्यासका दृष्टिले माध्यमिक तहका सबै कथामा कमीकमजोरी रहेको पाइयो। तापनि कथामा विन्यस्त अनुच्छेदहरूमा निहित मूल आशयसँग अन्य सहायक आशयको आर्थी संयोजन कायम भएकाले कथाहरू बोधगम्य एवम् ग्राह्य बनेको देखियो। सन्दर्भपरक संयुक्ति विन्यासका दृष्टिले हेर्दा माध्यमिक तहका आख्यानात्मक विधामा कथात्मक क्षेत्र वा विषय आनुभविक र तार्किक माध्यमबाट, पात्र वा सहभागी तिनको भूमिका वा चरित्रका माध्यमबाट र भाषिक माध्यम वा पद्धति विषय र सहभागीका माध्यमबाट प्रकाशित भएको पाइयो। साथै कथागत क्षेत्र, सहभागी र माध्यमका बीच उपयुक्त तालमेल कायम भई कथाहरू संयुक्तियुक्त बन्न पुगेको देखियो ।

माध्यमिक तहका आख्यानात्मक विधाको सड्कथन विश्लेषणमा आधारित प्रस्तुत अनुसन्धानले सङ्कथनसम्बद्ध संसक्ति, संयुक्ति अध्ययन तथा नेपाली भाषाको सड्गतियुक्त एवम् सार्थक शिक्षणका लागि समेत महत्त्वपूर्ण योगदान पुच्याउने अपेक्षा गरिएको छ। यस अनुसन्धानले माध्यमिक तहमा समाविष्ट कथाहरूको संसक्तिगत, संयुक्तिगत र शैक्षणिक स्थितिबारे जानकारी प्राप्त गर्न, साहित्यिक विधा वा पाठलाई साङ्कथनिक संसक्ति, संयुक्ति र शैक्षणिक कोणबाट सूक्ष्मतर रूपमा अध्ययन-विश्लेषण गर्न, कुनै पनि तहका लागि साङ्कथनिक दृष्टिले उपयुक्त विधागत रचना छनोटको सुक्क प्राप्त गर्न, भाषिक सड्कथन वा पाठमा निहित संरचनात्मक तथा अर्थतात्विक त्रुटिको पहिचान गर्न र त्यसलाई सच्याउन वा मूल्याड्कन गर्न सघाउने विश्वास लिएएको छ। यसर्थ यो अनुसन्धान माध्यमिक तहमा अध्यापनरत शिक्षक, अध्ययनरत विद्यार्थी, भाषापाठ्यक्रम निर्माता, भाषापाठ्यपुस्तक लेखक, योजनाकार, उच्च तहका विद्यार्थी, प्राजिक, व्यक्तित्व तथा साङ्कथनिक क्षेत्रमा रुचि राख्ने वा अध्ययन, अुनसन्धान गर्न चाहने शोधार्थी सबैका लागि उपयोगी हुने ठानिएको छ। (शब्द सड्ख्या : 9000)

\section{निष्कर्ष}

समग्रतः शोधसार कुनै पनि अनुसन्धानको मुख्य सारका रूपमा देखा पई। यसलाई अनुसन्धानको एउटा महत्त्वपूर्ण अवयवका रूपमा लिइन्छ। व्याख्यात्मक वा डिस्क्रिप्टिभ शोधसार, सूचनामूलक वा इन्फर्मेटिभ शोधसार, समालोचनात्मक वा क्रिटिकल शोधसार र चित्रात्मक वा ग्राफिकल शोधसार शोधसारका मुख्य प्रकारका रूपमा देखापर्छन्। कुनै पनि शोधसारमा आफूले गरेको शोध वा अनुसन्धान केमा गरिएको हो ? अध्ययन वा अनुसन्धानका क्रममा केके गरियो ? अध्ययन-अनुसन्धानबाट केके पत्ता लगाइयो ? पत्ता 
लगाइएका कुराहरू ककसका लागि उपयोगी छन् ? लगायतका कुराहरू आउनुपर्ने मानिन्छ । अर्थात् शोधसार परिचय, अध्ययन विधि, परिणाम वा प्राप्ति र निष्कर्ष एवम् उपायोगिता जस्ता अवयवहरूले युक्त हुनुपर्ने हुन्छ। यी अवयवहरू अन्तर्गत लेखिने कुराहरू पनि निश्चित हुन्छन् । एपिए (अमेरिकन साइकोलजिकल एसोसिएसन) को छौटौं संस्करणमा लेखसार लेखन १४० देखि २०० शब्दसम्मको हुनुपर्ने, लेखसार एउटै अनुच्छे,दको हुनुपर्ने, लेखसारको लेखन परिचयको सारबाट प्रारम्भ गर्नुपर्ने, त्यसपछि, विधिको सार अनि परिणाम र व्याख्याको सार लेख्नुपर्ने लगायतका मान्यता उल्लेख गरिएको भए पनि शोधसार लेखनमा तह र संस्थाअनुसार विविध ढाँचाहरू प्रयोग-व्यवहारमा रहेका छन् । अनुसन्धान एवम् भाषिक अनुसन्धानका सन्दर्भमा शोधसारलाई सम्बन्धित संस्थाले तयार गरेको ढाँचा वा निर्धारित नियमअनुरूप प्रयोग-व्यवहार गर्नु उपयुक्त देखिन्छ।

\section{सन्दर्भ सामग्री}

अमेरिकन साइकलजिकल एसोसिएसन (सन् २००९) पब्लिकेसन म्यानुअल अफ द अमेरिकन साइकलजिकल एसोसिएसन (छैटौं सं), वासिड्टन, डी. सी. : अथर ।

कुमार, रज्जित (सन् २००९), रिसर्च मेथोडोलोजी अ स्टेप बाइ स्टेप गाइड फर बिगिनर्स, अस्ट्रेलिया : पियर्सन एजुकेसन ।

डेन्जिन, के. एन. एम. र लिड्कन, एस. आइ. (सम्पा.) (सन् २००४), द सेज हेन्डबुक अफ क्वालिटेटिभ रिसर्च, लन्डन : सेज पब्लिकेसन ।

बोर्को, ह्यारोल्ड र बर्नियर, चार्ल्स एल. (१९७१), एव्ट्य्याक्टिड् कन्सेप्टस् एन्ड मेथड्स, न्यूयोर्क : एकेडेमिक प्रेस ।

लड्कास्टर, एफ. डब्लु. (9९९9), इन्डेक्सिड् एन्ड एब्ट्य्याक्टिड् इन थियरी एन्ड प्राक्टिस, इलिनोइस : ग्रयाजुएट स्कुल अफ लाइब्रेरी एन्ड इन्फरमेसन साइन्स, आइ. एल. युनिभर्सिटी अफ इलिनोइस। 